\title{
EFFECT OF URBAN TRAFFIC ON THE IMMISSION OF CARBON DIOXIDE IN THE UNIVERSITY CAMPUS
}

\author{
WPŁYW RUCHU POJAZDÓW W MIEŚCIE NA IMISJE DITLENKU WEGLA \\ NA TERENIE KAMPUSU UCZELNI WYŻSZEJ
}

\begin{abstract}
The condition and quality of atmospheric air plays a very important role in the life of every living organism, including man. Every day we breathe atmospheric air containing $\mathrm{CO}_{2}$ whose level changes depending both on many external factors and physicochemical processes. The concentration of carbon dioxide in the air changes, among other things, due to the influence of communication routes which may adversely affect the environment. For this reason it is necessary to analyze changes in $\mathrm{CO}_{2}$ concentrations and try to determine their impact on the functioning of users of the area (so, one can observe and analyze seasonal impact of communication routes on separate sub-areas of research).
\end{abstract}

Keywords: carbon dioxide, immission, concentration in the atmosphere

\section{Introduction}

Atmospheric air quality plays a very important role in the life of every living organism, including man. Especially, city dwellers who are exposed to pollution resulting from increasing number of people inhabiting a limited area, development of industry and energy demand, road and transport system, as well as the presence of natural sources of emissions.

Regular and accurate measurements of $\mathrm{CO}_{2}$ concentrations in the atmosphere started in the 50s of the twentieth century (periodic measurements have been carried out since 1955 in the observatory at the top of Mauna Loa volcano in Hawaii). Thus, it has been noted that from year to year there is a systematic increase in the concentration of carbon dioxide in the atmosphere (with about 315 parts per million - ppm in 1958 to over $380 \mathrm{ppm}$ in 2006) [1]. Figure 1 shows changes of the global carbon dioxide levels in the last few hundred years $[2]$.

\footnotetext{
${ }^{1}$ Faculty of Architecture, Civil and Environmental Engineering, Lodz University of Technology, al. Politechniki 6, 90-924 Łódź, Poland, phone +48 4263135 14, fax +48 $42 \quad 6313516$, email: robert.cichowicz@p.lodz.pl

${ }^{2}$ Faculty of Process and Environmental Engineering, Lodz University of Technology, ul. Wólczańska 213, 90-924 Łódź, Poland, phone +48 4263137 95, fax +48 4263656 63, email: grzegorz.wielgosinski@p.lodz.pl

*Corresponding author: robert.cichowicz@p.lodz.pl
} 


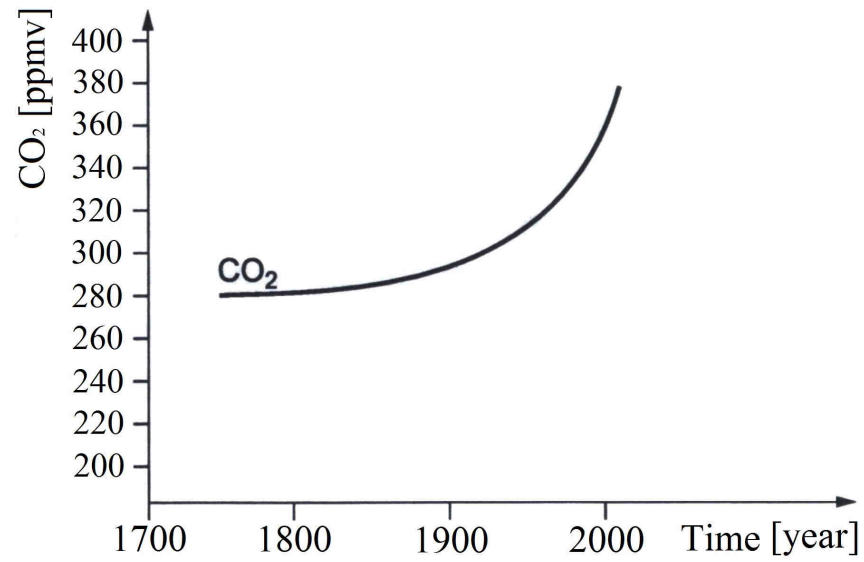

Fig. 1. Changes in the concentration of carbon dioxide [2]

According to Solomon et al [3] climate changes are caused by an increase in the concentration of carbon dioxide and may be irreversible (the authors estimate that after the emissions stop it would take about 1,000 years to return to the previous state), and the levels of average concentrations of $\mathrm{CO}_{2}$ in the atmosphere would be likely to increase from the current 385 ppm to $450-600$ ppm.

Such levels of carbon dioxide may cause acceleration of photosynthesis, and thus have an influence on potential climate changes and a negative impact on humans, animals and vegetation [4-6].

In Poland, systematic measurements of carbon dioxide concentrations have been conducted for about 20 years at Kasprowy Wierch in the Tatra Mountains in the KASLAB laboratory located in the building of the IMGW meteorological observatory. It is the only station in Central and Eastern Europe with such a long record of concentrations of the main greenhouse gases in the atmosphere. The first measurements of $\mathrm{CO}_{2}$ concentrations in the atmosphere at Kasprowy Wierch started in September 1994. At first (until 1996) the measurements of averaged weekly air samples were performed. Since 1996, the measurements have been carried out by gas chromatography method using an automatic HP 5890 chromatograph equipped with a flame ionization detector and a column packed with Porapak QS [7].

For the first time on a global scale the issue of reducing emissions of greenhouse gases, including carbon dioxide, was raised in 1992 under the United Nations Framework Convention on Climate Change - UNFCCC. One of the most important protocols that refer to the issue of limiting greenhouse gas emissions is the Kyoto Protocol of 1997, which is now better known than the Convention itself. Under provisions of this Protocol countries that have opted for its ratification committed themselves to reduce their emissions by negotiated values of gases such as, inter alia, carbon dioxide, methane and nitrous oxide, $i e$ the gases which cause the greenhouse effect.

Currently, in the Polish legislation a superior document related to air protection is the Environmental Protection Law [8] which identifies the principles of protection of the environment and conditions for the use of its resources, taking into account the 
requirements of sustainable development, rules for determining the conditions of conservation of the environment, the conditions of introducing substances or energy into the environment, and the cost of using the environment. According to the provisions of the above mentioned Law, the protection of air covers ensuring its best possible quality by maintaining pollutant concentrations below the maximum levels specified by regulations. Air protection consists also in a reduction of the concentrations of substances in the air to acceptable levels at least. The Law does not define carbon dioxide as a substance that adversely affects the quality of atmospheric air. The level of $\mathrm{CO}_{2}$ in the atmosphere is not defined as acceptable and is therefore not monitored by the State Environmental Monitoring (monitoring of this gas is carried out only for the purpose of emissions trading).

The all Polish environmental law is based on EU environmental legislation, and was implemented before accession in 1999-2001. The main regulation on the air protection is based on CAFÉ Directive [9].

\section{Immission and emission}

According to the Polish Environmental Protection Law [8]: "emission are the substances and energy such as heat, noise, vibrations or electromagnetic fields introduced directly or indirectly into the atmosphere, water, soil or earth as a result of human activity", while "immission is the concentration of pollutants or deposition of pollutants in the environment. The source of immission can be one, but usually many sources of pollution which typically consist of a number of emissions from various sources of pollution".

The sources of air pollutant emissions are mainly local (central and local) and district heating systems that provide heat for housing, industry and services generating harmful substances in the atmosphere [10-12].

It should be borne in mind that low-emission sources emit pollutants only in the heating season, while district heating systems do this with varying intensity throughout the calendar year. To estimate the amount of fuel used and to determine on this basis the amount of pollutants is possible only for centralized heating systems, while for low-emission sources this is difficult because the size of pollution is determined by weather, local fuel availability and the lack of emission control levels [10].

Another, and sometimes even more important source of air pollution is road transport which often (especially in the centers of large cities) has a more negative impact on the environment than the heating systems themselves [13-15]. This is due to the fact that especially in large urban areas the flow of traffic increases steadily, thus deteriorating air quality (according to the Central Statistical Office $\mathrm{CO}_{2}$ emissions from transport in Poland increased from 26,403.76 thousand $\mathrm{Mg}$ in 2000 to 46,465.74 thousand $\mathrm{Mg}$ in 2010 [16]).

The levels of carbon dioxide immissions are closely related to the emission of this pollutant to the atmosphere and occur cyclically (daily, seasonally, annually), while immission fields are not dependent on the location of emitters from district systems.

One of the methods to reduce the level of pollutants in ambient air is to reduce the size of cities through the creation of so-called compact cities in which the negative effects of urbanization on the environment could be prevented or reduced [17]. Unfortunately, this concept is not always feasible due to the nature of the region, its industrialization and historical conditions. 


\section{Characteristics of the studied area}

Changes in the carbon dioxide immission field were investigated in campus $\mathrm{B}$, ie in southern part of the Lodz University of Technology which on the north is adjacent to Skorupki St. through the Bishop Klepacz Park, and on other sides is surrounded by Wolczanska St. (on the east), Wroblewskiego St. (from the south) and al. Politechniki (on the west). Additionally, on the south-west there is the city's power plant EC2.

The area covers about 16 hectares of which large part is occupied by the $19^{\text {th }}$ century palaces and revitalized industrial buildings of the former LODEX factory. The complex comprises 19 buildings belonging to the Lodz University of Technology. Significant parts of campus B are rigid pavements, such as access roads and parking lots. The area is characterized by the diversity of buildings. There are both densely built-up and green areas. The most densely built-up area is occupied by the building of "Three Departments" along with the buildings of the Center for Laser Diagnostics and Therapy, Faculty of Process and Environmental Engineering (FPEE) and the Institute of Turbomachinery. The lowest building density has the area of FPEE Dean's Office (Fig. 2).

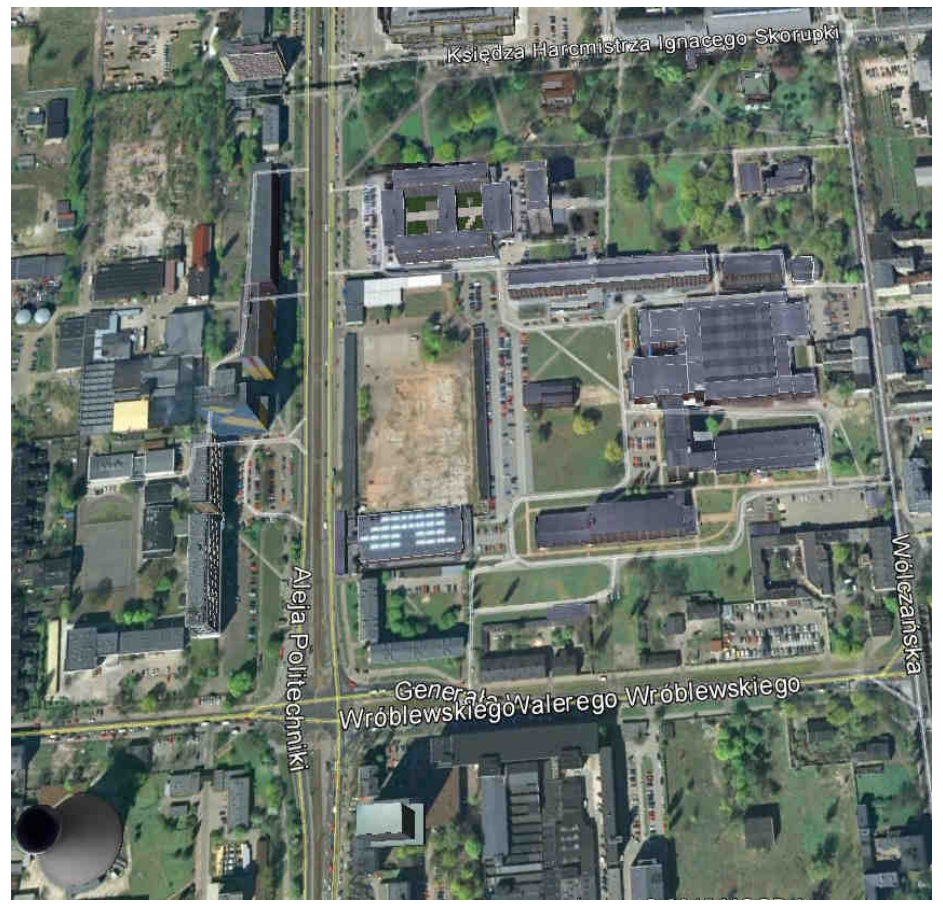

Fig. 2. View of campus B [18]

Measuring points were located in the corners of the existing buildings. Due to the type of building, on the west side there were much less measuring points than on the east side (Fig. 3). Measurements were taken in March and April in 2012 and 2014. Each time in March, the measurements were made in 83 points, while in April in 86 points extending 
the research area with 2 points localized along al. Politechniki and 1 point at Wroblewskiego St.

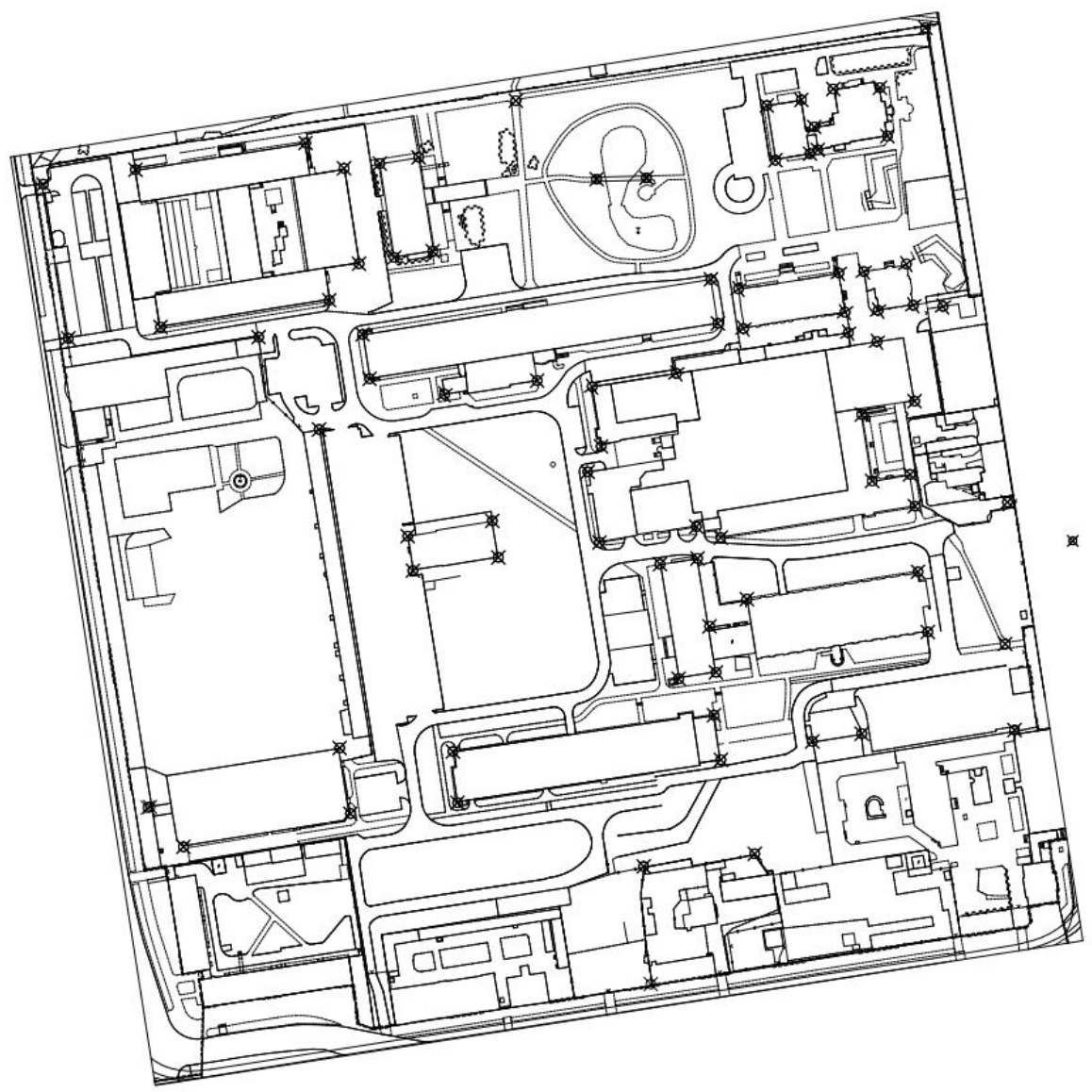

Fig. 3. Measuring points on the area of campus B

\section{The measurement methodology}

In the measurements a VEGA-GC microchromatograph (Pollution S.p.A., Italy) was used (Fig. 4). With this device analysis can be made in field conditions. The device is equipped with 2 batteries, a tank with carrier gas (helium), a pump for samples and a computer module. In the device two columns operating in parallel can be installed (Table 1 gives basic information on the possibilities of measurements using different columns installed in the VEGA GC microchromatograph). A thermal conductivity detector (TCD) enables the analysis of samples at a minimum concentration of $500 \mathrm{ppb}(0.005 \mathrm{ppm})$ over a period of 6 to 300 seconds depending on the type of gas tested [19]. 
a)

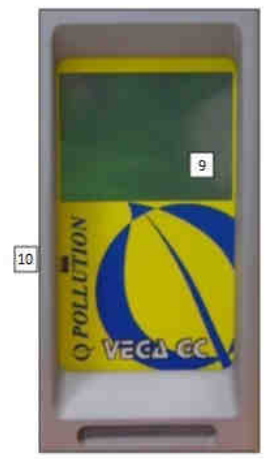

b)

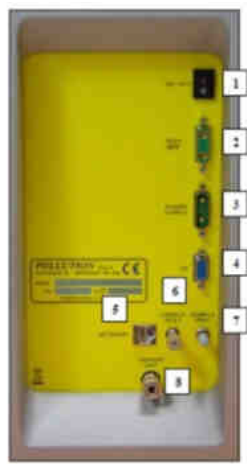

Fig. 4. The image of VEGA-GC microchromatograph (a and b) [19]: 1 - on/off switch; 2 - port of multipoint connector of the VEGA MPS sampler (additional equipment); 3 - port of the external power connector 110-220 V AC - 12/24 V DC; 4 - RS-232 or RS-485 connector (possibility of connecting external monitor screen); 5 - LAN Ethernet port (possibility of connecting the device to local network or Internet); 6 - sample inlet; 7 - sample outlet; 8 - carrier gas connector (possibility of connecting external cylinder with carrier gas); 9 - LCD touch screen 6.5"; 10 - USB port (possibility of exporting data to external storage, connecting external keyboard/mouse and external printer)

Columns of VEGA-GC microchromatograph [19]

\begin{tabular}{|c|c|c|}
\hline $\begin{array}{c}\text { Name of } \\
\text { column }\end{array}$ & Description & Exemplary gases \\
\hline CP Sil 5CB & $\begin{array}{c}\text { capillary column } \\
\text { packing: pure (100\%) methyl group } \\
\text { on a silicone scaffold; application: } \\
\text { hydrocarbons containing carbon } \\
\text { particles from C3 to C8 (C10), } \\
\text { aromatic hydrocarbons of high } \\
\text { boiling point } \\
\end{array}$ & $\begin{array}{l}\text { benzene; toluene; xylene; pentane; propane; } \\
\text { ethylbenzene; decane; heptane; hexane; ethanol; } \\
\text { acetone; chlorofluorocarbons (CFCs); } \\
\text { formaldehyde; methanol }\end{array}$ \\
\hline PPQ & $\begin{array}{c}\text { packed column, application: } \\
\text { hydrocarbons containing carbon } \\
\text { particles from } \mathrm{C} 1 \text { to } \mathrm{C} 4\end{array}$ & $\begin{array}{l}\mathrm{N}_{2} ; \mathrm{N}_{2} \mathrm{O} ; \mathrm{H}_{2} \mathrm{O} ; \mathrm{CO}_{2} ; \mathrm{CH}_{4} ; \text { acetylene; ethane; } \\
\text { chloroethane; ethanol; ethylene; propane }\end{array}$ \\
\hline $\begin{array}{l}\text { Molsieve 5A } \\
\text { (M5ABF) }\end{array}$ & $\begin{array}{c}\text { packed column, application: carbon } \\
\text { monoxide, methane }\end{array}$ & $\mathrm{CO} ; \mathrm{H}_{2} ; \mathrm{CH}_{4} ; \mathrm{N}_{2} ; \mathrm{O}_{2} ; \mathrm{He} ; \mathrm{Ar} ; \mathrm{Ne}$ \\
\hline $\begin{array}{l}\text { CP Wax } 52 \\
\quad(52 \mathrm{CB})\end{array}$ & $\begin{array}{c}\text { capillary column } \\
\text { packing: polyethylene glycol } \\
\text { application: polar substances of } \\
\text { high boiling temperature }\end{array}$ & $\begin{array}{l}\text { acetone; acetaldehyde; acetic acid; methanol; } \\
\text { ethanol; propanol; butanol; methylbutane; hexanol; } \\
\text { C1-C4 glycols }\end{array}$ \\
\hline
\end{tabular}

Technical data of the device [19]:

1. Power supply: adapter 110-220 V AC - 12/24 V DC; 2 nickel-metal-hydrogen batteries (NiMh).

2. Carrier gas: possibility of using helium, hydrogen, nitrogen or argon from an external source - gas cylinder. Required flow rate $-10 \mathrm{~cm}^{3} / \mathrm{min}$; possibility of using helium, hydrogen, nitrogen or argon from an external source - gas cylinder. Required flow rate $-10 \mathrm{~cm}^{3} / \mathrm{min}$.

3. Dimensions: $17 \times 38 \times 41 \mathrm{~cm}($ width $\times$ height $\times$ depth $)$. 
4. Weight: 9 kilos without batteries; 13 kilos with two installed batteries.

5. User interface: color touch screen LCD with a diagonal of 6.5".

6. Working conditions: operating humidity $0-95 \%$; working temperature: $0-50^{\circ} \mathrm{C}$.

7. Characteristics of samples: sample temperature $0-120^{\circ} \mathrm{C}$; sample pressure $50-200 \mathrm{kPa}$.

8. Working time: 60-300 s (depending on the number of analyzed substances).

9. Detector: thermo-conductive TCD.

10. Calibration: every 6 months.

11. Minimum concentration: $500 \mathrm{ppb}$ (parts per billion) (1 billion - $\left.10^{9}\right)$ solvent molecules.

12. Operation system: WINDOWS XP EMBEDDED.

Measurements of carbon dioxide concentrations were made in the PPQ packed column installed in the VEGA-GC microchromatograph. Each measurement was performed at a $90 \mathrm{~s}$ interval.

To evaluate a specific type of pollutant and its amount the chromatograph was calibrated on the basis of test gas. Figure 5 shows a calibration curve.

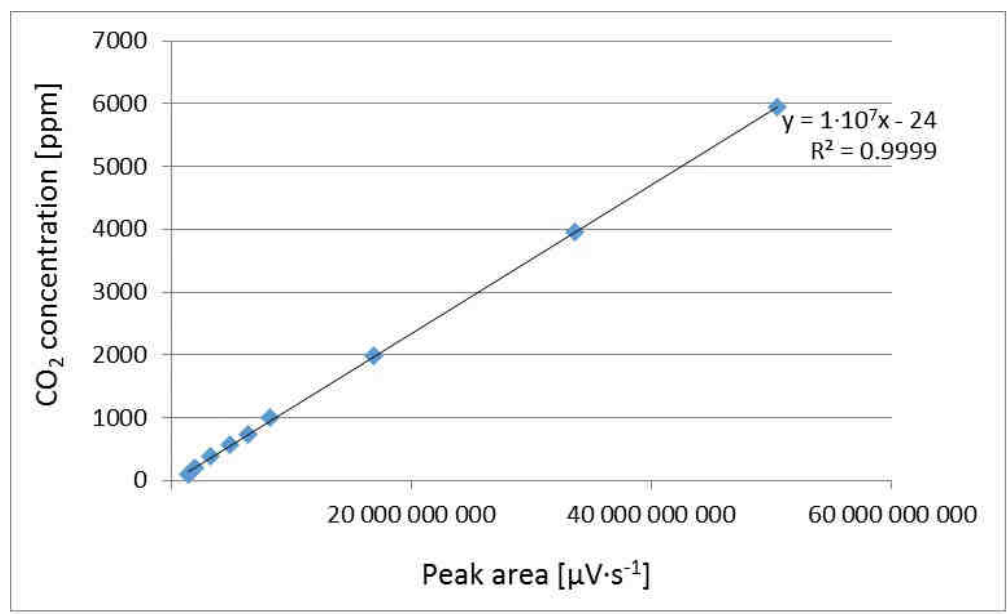

Fig. 5. Plot of the calibration curve for carbon dioxide [20]

A method developed by Cichowicz for carbon dioxide measurement with the use of VEGA-GC microchromatograph was applied in the study. In the first step, two batteries were charged and then mounted and a portable bottle with carrier gas (helium) was installed. Next, the operating system (computer) was started and connected to MC2 and MC-Plan program in order to tune the device. The next step was launching the program with a defined methodology of carbon dioxide measurement. After heating the device, the process of automatic measurement was started and the researchers went to the first measuring point. During the measurements the measuring device was set in the direction free from buildings (in the vicinity of the pavement). Due to 83 and 86 measuring points, an external device equipped with a GPS receiver was used and at the start of sample supply to the device on the memory card the date, time and GPS coordinates were saved. Then, on a geodesic map the surface of the built-up area, ie the sum of surfaces of ground floors of all buildings in the area calculated in the outer wall contours (with clearances and arcades) was 
determined. The number of storeys in the buildings in the analyzed areas was specified and an average storey height of the buildings was assumed. Thanks to this, multiplying the built-up area by the number of storeys and their average height we obtained cubic capacity of the building. When dividing the surface of the area by the sum of cubic capacities of the built-up area we obtain an estimated building density of the area. This quantity is related to the arithmetic mean of carbon dioxide concentration recorded in the measuring points located in the area.

To determine the meteorological conditions during the measurements, data from the weather station located in the Wladyslaw Reymont airport in Lodz were used [21]. The weather station is about $5 \mathrm{~km}$ from campus B in a bee line.

Table 2 summarizes the basic values of meteorological data, which were recorded at the Lodz-Lublinek station for days and hours during which the measurements were made.

Weather data [21]

Table 2

\begin{tabular}{|c|c|c|c|c|c|c|c|c|}
\hline $\begin{array}{c}\text { Date of } \\
\text { measurement/ } \\
\text { Parameter }\end{array}$ & $\mathbf{2 0 . 0 3 . 1 2}$ & $\mathbf{0 2 . 0 4 . 1 2}$ & $\mathbf{2 3 . 0 4 . 1 2}$ & $\mathbf{2 5 . 0 4 . 1 2}$ & $\mathbf{2 0 . 0 3 . 1 4}$ & $\mathbf{0 3 . 0 4 . 1 4}$ & $\mathbf{2 4 . 0 4 . 1 4}$ & $\mathbf{2 8 . 0 4 . 1 4}$ \\
\hline $\begin{array}{c}\text { Temperature } \\
{\left[{ }^{\circ} \mathrm{C}\right]}\end{array}$ & $9-13$ & 7 & $9-13$ & 15 & $11-15$ & $8-19$ & $8-19$ & $13-16$ \\
\hline $\begin{array}{c}\text { Cloudiness } \\
\text { overcast }\end{array}$ & $\begin{array}{c}\text { partly } \\
\text { overcast }\end{array}$ & $\begin{array}{c}\text { partly } \\
\text { overcast }\end{array}$ & cloudless & $\begin{array}{c}\text { light } \\
\text { overcast }\end{array}$ & cloudless & cloudless & $\begin{array}{c}\text { partly } \\
\text { overcast }\end{array}$ \\
\hline $\begin{array}{c}\text { Wind flow } \\
\text { velocity } \\
\text { [km/h] }\end{array}$ & $22-31$ & $26-30$ & $9-15$ & $13-19$ & $17-33$ & $6-13$ & $17-21$ & $6-17$ \\
\hline $\begin{array}{c}\text { Wind } \\
\text { direction }\end{array}$ & W & W & SW & SW & W & W & W & SW \\
\hline Pressure [hPa] & 1031.2 & 1005.1 & 1008.1 & 1005.8 & 1018.5 & 1005.1 & 1019.8 & 1009.1 \\
\hline $\begin{array}{c}\text { Relative } \\
\text { humidity [\%] }\end{array}$ & $53-70$ & $49-53$ & $51-81$ & $44-82$ & $55-72$ & $40-57$ & $46-64$ & $72-94$ \\
\hline
\end{tabular}

\section{Fields of carbon dioxide immission}

As a criterion for the analysis of air quality in campus B the impact of two arterial roads, ie al. Politechniki (Figs. 6 and 7) and Wolczanska St. (Figs. 8 and 9), was assumed. Results of the measurements were classified according to distance from the roads. Four sections were established: 0-50, 50-100, 100-150 and 150-200. In the particular sub-areas arithmetic means of carbon dioxide concentrations were determined. On this basis the impact of communications routes on air quality in the tested area could be observed. Due to the specific nature of campus B, on the side of Al. Politechniki much fewer measuring points were located than on the side of Wolczanska St. For these reasons, while analyzing the impact of the roads on the tested area a different number of measuring points was taken to determine the average concentration of carbon dioxide.

In March 2012 and 2014 the average carbon dioxide concentration in the sub-area which was closest to Al. Politechniki was 373 ppm each time, while in April 2012 and 2014 it was $706 \mathrm{ppm}$ and $369 \mathrm{ppm}$, respectively. It was observed that in both years in March these values were decreasing with increasing distance from Al. Politechniki. On the other hand, basing on the measurements taken in March 2012 and 2014, on the side of Wolczanska St. an increase of carbon dioxide concentration with distance from the road 
could be observed. This may be caused by an increase in housing density and traffic on the roads inside campus B as well as by use of students' parking lots in close proximity to the tested area.

The situation was quite different in April 2012, when the average concentration of carbon dioxide increased with distance from Al. Politechniki, and decreased with distance from Wolczanska St. However, in April 2014, the average concentration of carbon dioxide varied within the same range irrespective of the distance from Al. Politechniki, and decreased with increasing distance from Wolczanska St.
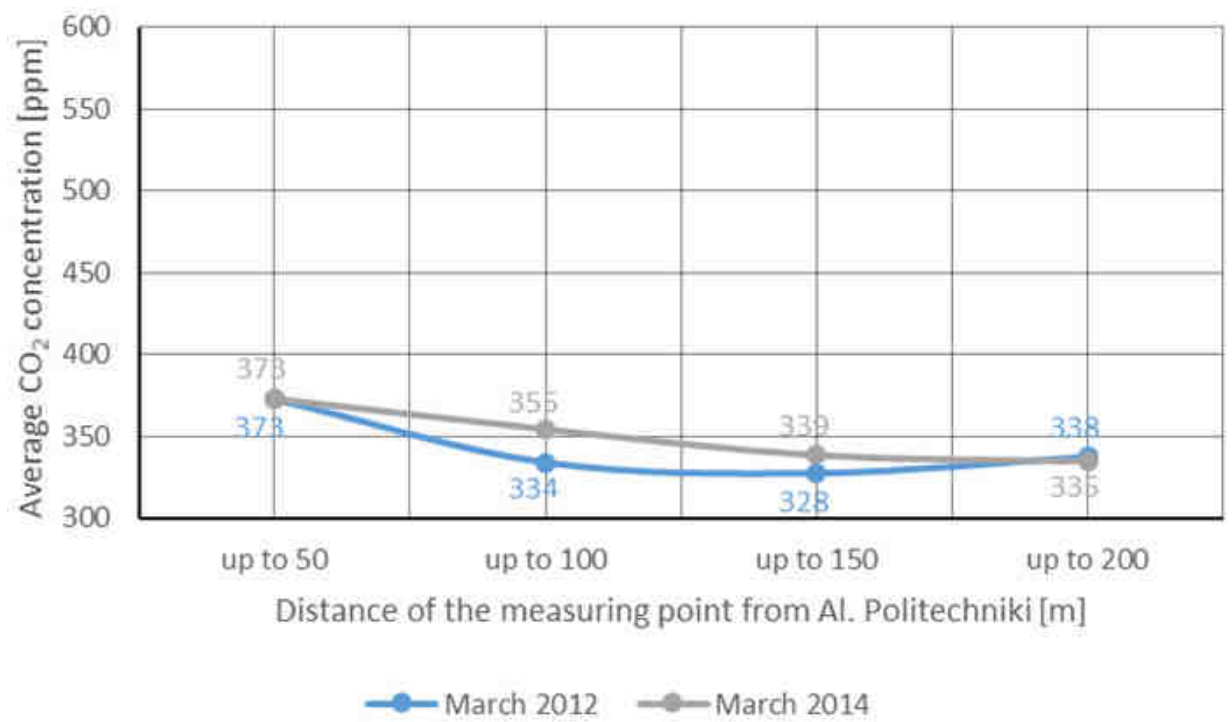

Fig. 6. Impact on campus B, Al. Politechniki, March 2012 and 2014

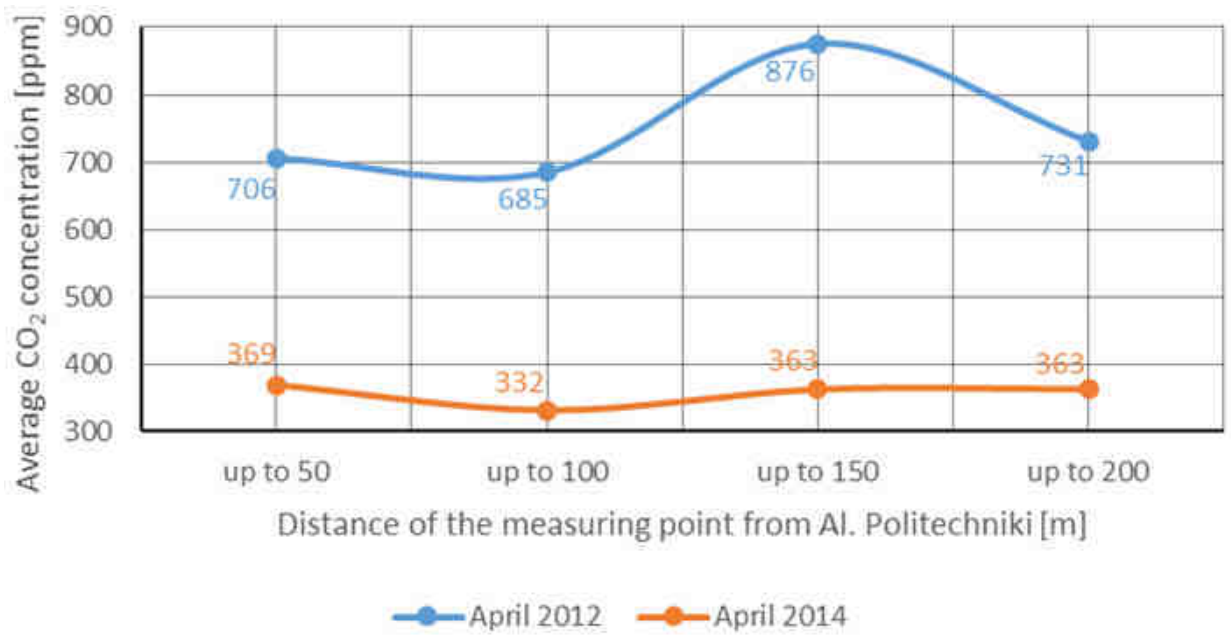

Fig. 7. Impact on campus B, Al. Politechniki, April 2012 and 2014 


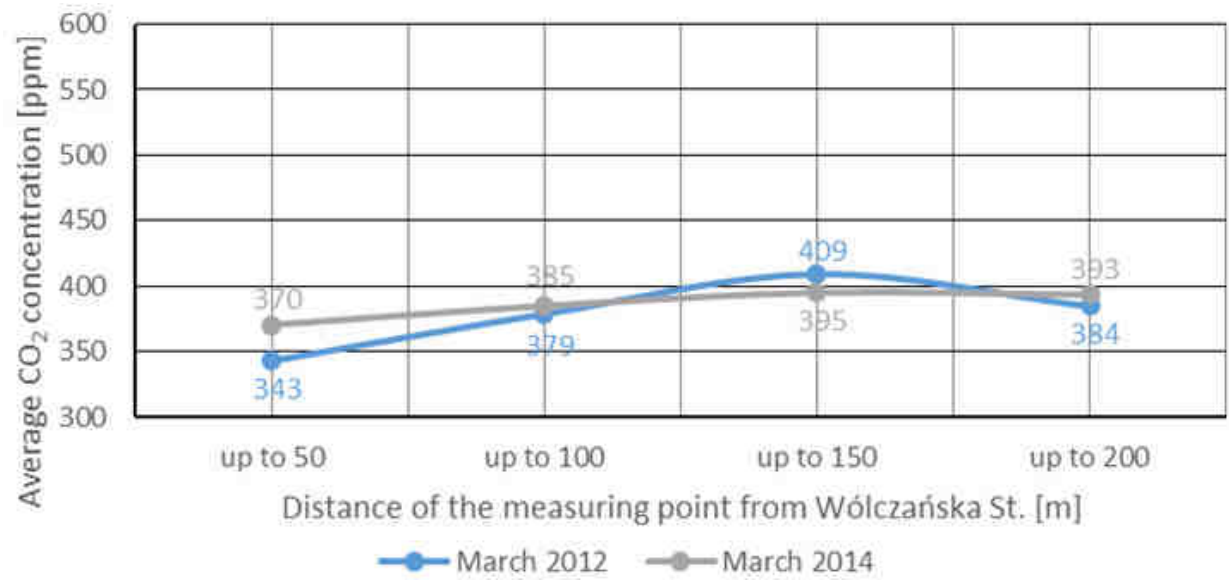

Fig. 8. Impact on campus B, Wolczanska St., March 2012 and 2014

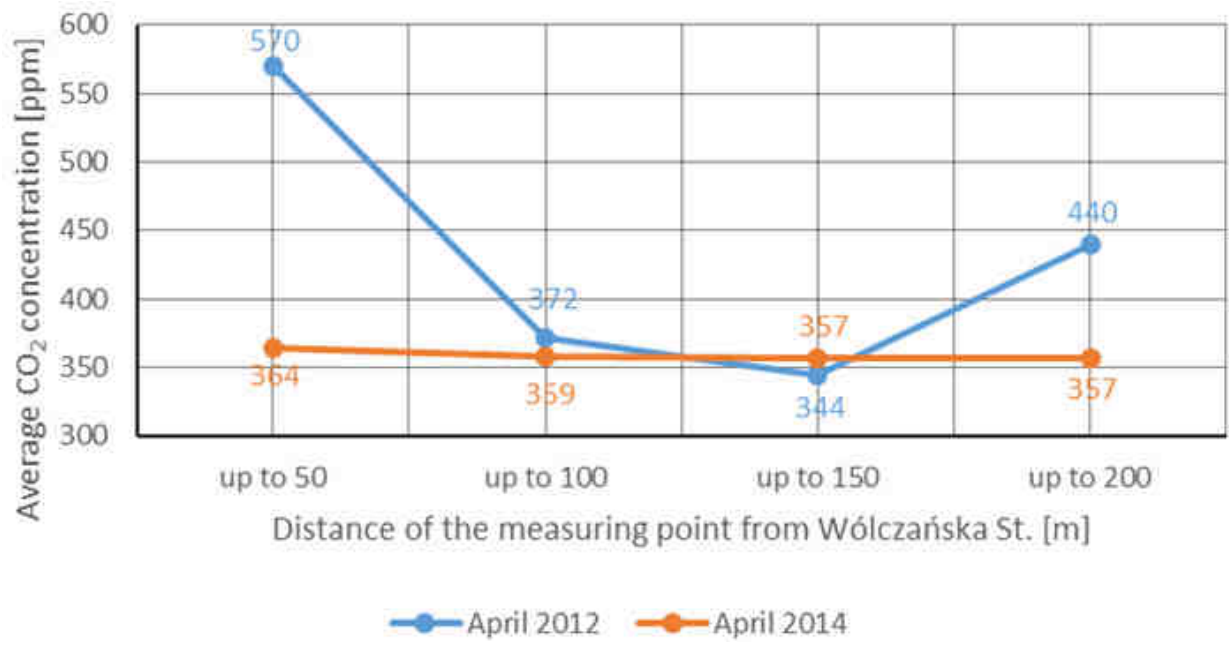

Fig. 9. Impact on campus B, Wolczanska St., April 2012 and 2014

\section{Conclusions}

Every analysis of changes in the field of pollutant immission in a given area can be useful for monitoring the atmosphere and should be periodically or continuously carried out and continually improved. After access to the European Union, Poland introduces more and more effectively new methods to improve the monitoring system. Systematic attempts are made to reduce pollution from large industrial plants using, for instance, the best available techniques. However, as regards gases emitted from district heating systems they are purified to the level specified in permits for emissions and their potential exceedance causes serious financial consequences. 
The use of gas microchromatography enables precise and accurate measurements of carbon dioxide concentrations. Based on the tests carried out in this study it can be assumed that in the analyzed area there are only local variations in $\mathrm{CO}_{2}$ concentrations which can adversely affect the functioning of the users of the area. Additionally, a seasonal impact of communications routes on separate sub-areas was observed.

\section{References}

[1] http://scrippsco2.ucsd.edu.

[2] Janka RM. Zanieczyszczenia pyłowe i gazowe. Podstawy obliczania i sterowania poziomem emisji. Warszawa: Wyd Nauk PWN; 2014.

[3] Solomon S, Plattner GK, Knuttic R, Friedlingsteind P. Irreversible climate change due to carbon dioxide emissions. Proc Natl Acad Sci USA. 2009;106(6):1704-1709. DOI: 10.1073/pnas.0812721106.

[4] Allen LH. Plant responses to rising carbon dioxide and potential interactions with air pollutants. J Environ Qual. 1990;19(1):15-34. DOI: 10.2134/jeq1990.00472425001900010002x.

[5] Idso $\mathrm{CD}$, Idso SB, Balling RCJr. The urban $\mathrm{CO}_{2}$ dome of Phoenix, Arizona. Physical Geography. 2013;19(2):95-108. DOI: 10.1080/02723646.1998.10642642.

[6] Ziska LH, Bunce JA, Goins EW. Characterization of an urban-rural $\mathrm{CO}_{2}$ /temperature gradient and associated changes in initial plant productivity during secondary succession. Oecologia. 2004;139(3):454-458. DOI: 10.1007/s00442-004-1526-2.

[7] Chmura L, Rozanski K, Necki JM, Zimnoch M, Korus A, Pycia M. Atmospheric concentrations of carbon dioxide in southern Poland: Comparison of mountain and urban environments. Polish J Environ Stud. 2008;17(6):859-867. http://www.pjoes.com/pdf/17.6/859-867.pdf.

[8] Environmental Protection Law (Ustawa Prawo Ochrony Środowiska) - O.J. (Poland) 2001;62: item. 627.

[9] Directive 2008/50/EC of the European Parliament and of the Council of 21 May 2008 on ambient air quality and cleaner air for Europe (CAFÉ) - O.J. of EU 2008;51(152):1-44, 11.06.2008.

[10] Skrzypski J. Analiza i modelowanie pól immisji zanieczyszczeń powietrza w dużych miastach (na przykładzie Łodzi). Łódź: Polska Akademia Nauk, Oddział w Łodzi; 2002.

[11] Nemitz E, Hargreaves KJ, McDonald AG, Dorsey JR, Fowler D. Micrometeorological measurements of the urban heat budget and $\mathrm{CO}_{2}$ emissions on a city scale. Environ Sci Technol. 2002;36(14):3139-3146. DOI: 10.1021/es010277e.

[12] Gurney KR, Razlivanov I, Song Y, Zhou Y, Benes B, Massih MA. Quantification of fossil fuel $\mathrm{CO}_{2}$ emissions on the building/street scale for a large U.S. city. Environ Sci Technol. 2012;46(21):12194-12202. DOI: 10.1021/es3011282.

[13] Chang $\mathrm{CH}$, Meroney RN. Concentration and flow distributions in urban street canyons: wind tunnel and computational data. J Wind Eng Industrial Aerodyn. 2003;91:1141-1154. DOI: 10.1016/S0167-6105(03)00056-4.

[14] Vogt R, Christen A, Rotach MW, Roth M, Satyanarayana ANV. Temporal dynamics of $\mathrm{CO}_{2}$ fluxes and profiles over a Central European city. Theoret Appl Climatol. 2006;84(1-3):117-126. DOI: 0.1007/s00704-005-0149-9.

[15] Matese A, Gioli B, Vaccari FP, Zaldei A, Miglietta F. Carbon dioxide emissions of the city center of Firenze, Italy: Measurement, evaluation, and source partitioning. J Appl Meteor Climatol. 2009;48:1940-1947. DOI: 10.1175/2009JAMC1945.1.

[16] Główny Urząd Statystyczny. Departament Badań Regionalnych i Środowiska: Ochrona środowiska 2012. stat.gov.pl/cps/rde/xbcr/gus/se_ochrona_srodowiska_2012.pdf.

[17] The compact city and the environment: a review. Tijdschrift voor economische en sociale geografie: 2000;91(2):111-121. DOI: 10.1111/1467-9663.00099.

[18] Google Earth wersja programu 7.1.2.2041 (freeware).

[19] Pollution S.p.A. Karta katalogowa mikrochromatografu VEGA GC.

[20] Cichowicz R, Sabiniak H, Wielgosiński G. The influence of a ventilation on the level of carbon dioxide in a classroom at a higher university. Ecol Chem Eng S. 2015;22(1):61-71. DOI: 10.1515/eces-2015-0003.

[21] http://freemeteo.com/ 


\title{
WPŁYW RUCHU POJAZDÓW W MIEŚCIE NA IMISJĘ DITLENKU WĘGLA NA TERENIE KAMPUSU UCZELNI WYŻSZEJ
}

${ }^{1}$ Instytut Inżynierii Środowiska i Instalacji Budowlanych

Wydział Budownictwa, Architektury i Inżynierii Środowiska, Politechnika Łódzka

${ }^{2}$ Katedra Inżynierii Środowiska, Wydział Inżynierii Procesowej i Ochrony Środowiska, Politechnika Łódzka

\begin{abstract}
Abstrakt: Stan i jakość powietrza atmosferycznego odgrywają bardzo ważną rolę w życiu każdego organizmu żywego, w tym i człowieka. Na co dzień oddychamy powietrzem atmosferycznym, w którym występuje $\mathrm{CO}_{2}$, a jego poziom zmienia się $\mathrm{w}$ zależności zarówno od wielu czynników zewnętrznych, jak i procesów fizykochemicznych. Stężenia ditlenku węgla w powietrzu ulegają zmianie między innymi ze względu na wpływ arterii komunikacyjnych, które mogą negatywnie oddziaływać na otoczenie. $\mathrm{Z}$ tego powodu należy przeprowadzać analizy zmian stężeń $\mathrm{CO}_{2}$ i próbować określać ich wpływ na funkcjonowanie użytkowników danego terenu (dzięki temu można zaobserwować i przeanalizować sezonowy wpływ szlaków komunikacyjnych na wydzielone podobszary badań)
\end{abstract}

Słowa kluczowe: ditlenek węgla, imisja, stężenia w atmosferze 